Article

\title{
The Effect of Curing Conditions on Selected Properties of Recycled Aggregate Concrete
}

\author{
Anna M. Grabiec ${ }^{1} * * \mathbb{D}$, Daniel Zawal ${ }^{1}$ and Waheed Adewale Rasaq ${ }^{2}$ \\ 1 Institute of Construction and Geoengineering, Poznań University of Life Science, 60-649 Poznań, Poland; \\ daniel.zawal@up.poznan.pl \\ 2 Aqua Stone, 60-002 Poznań, Poland; waheedite2000@yahoo.com \\ * Correspondence: agra@up.poznan.pl; Tel.: +48-606-202-332
}

Received: 20 May 2020; Accepted: 24 June 2020; Published: 27 June 2020

\begin{abstract}
The paper presents the influence of different curing conditions-wet, dry, and protection against water evaporation (PEV)—on selected properties of concretes with different amounts of recycled concrete aggregate (RCA) previously subjected to atmospheric $\mathrm{CO}_{2}$ sequestration. Two types of cement were used, Portland cement and blast-furnace slag cement. The study was performed in laboratory conditions (at the temperature of $20 \pm 1{ }^{\circ} \mathrm{C}$ and relative humidity of about $60 \%$ ), according to currently applicable test procedures for most of the measured characteristics of concrete. Additionally, the eco-efficiency indexes $\left(b_{i}\right.$ and $\left.c_{i}\right)$ as well as the eco-durability S- $\mathrm{CO}_{2}$ index were calculated. It was found that dry conditions cause the properties of concrete to deteriorate, especially concrete made of blast-furnace slag cement, while PEV allows the achievement of results comparable to wet conditions. Moreover, for series with the highest amounts of coarse recycled aggregate and after longer periods of curing, the difference between the effects of wet curing and protection against water evaporation disappears. The eco-efficiency and eco-durability indexes approach confirms the beneficial effect of blast-furnace slag cement used as a binder, but on the condition of using a proper way of curing.
\end{abstract}

Keywords: curing conditions; carbonated recycled concrete aggregate; eco-efficiency indexes; eco-efficient index

\section{Introduction}

The annual production of concrete - as the most popular construction material-amounts to nearly 10 billion tons per year. Undoubtedly, significant consumption concerns mineral natural and crushed aggregates resulting from the crushing of rock raw materials. This leads, among other effects, to the depletion of natural resources, the violation of ecosystems, and carbon dioxide emission, the latter also resulting from the production of cement (in 2017 with a $4 \%$ share in global anthropogenic $\mathrm{CO}_{2}$ emission [1]), which, as well as aggregate, is a key component of concrete and despite a smaller share in the quantity of concrete compared to the share of aggregate, exceeds the emission from the exploitation of natural aggregates, the production of crushed aggregates, and the transport of aggregates [2]. Moreover, the construction industry generates large amounts of waste through the reconstruction and demolition of buildings, which means that it takes up space and engenders high costs for waste disposal.

The mitigation of the above-mentioned factors detrimental to the environment by using recycled concrete aggregate (RCA) is obvious. However, RCA is a material of a poorer quality (e.g., large porosity, water absorption, content of irregularly sharper grains, lack of uniformness, higher water demand) in comparison with the quality of natural aggregates. Special attention should be paid to the use of fine recycled aggregate (FRA) for its pernicious effect on the properties of cement matrix composites. The presence of FRA decreases compressive strength and water absorbability [3], more so with higher 
shares of FRA [3,4] and more significantly when fine recycled aggregate is soaked in comparison to its application in dry state. The pores of FRA are unable to fill with water completely during soaking [5]. Therefore, [6] proposes realizing the saturation process of FRA under vacuum, reaching a degree of saturation of $99.7 \%$. However, such an approach does not yet seem possible from an economic viewpoint. Thus, the use of FRA in concrete technology is still controversial and studies on it need to be developed.

The properties of RCA can be modified in different ways, among others by heating and rubbing $[7,8]$, ultrasonic cleaning [9], mechanical grinding, acid cleaning [10], and even biodeposition [11,12]. An effective method to improve the quality of recycled aggregate is to carbonate it [13-15].

A significant disadvantage of the recycled concrete aggregate-influenced durability of recycled aggregate concrete (RAC) is the moisture content in RCA [16]. One of the difficulties of manufacturing recycled aggregate concrete mixes is the apparent density of aggregate combined with its porosity [17], responsible for water absorbability, which is in the range of 3-10\% [18]. The water absorbability of recycled aggregates does not have to be a technological problem in the concrete manufacturing process, but only on condition that it is measured correctly. If it is underestimated, the workability of the concrete mix deteriorates, and the hydration processes are disturbed. Therefore, two ways of adding water to concrete mix are proposed, resulting from the water absorption of recycled aggregate [19]: compensation (the use of additional water resulting from the absorbability of recyclable aggregates) and the pre-soaking of RCA with water. The water absorption time of RCA is also essential. However, the authors of publications are not in agreement on this aspect. It is rare to achieve full saturation after $24 \mathrm{~h}$ or more, sometimes even taking up to $120 \mathrm{~h} \mathrm{[19].} \mathrm{According} \mathrm{to} \mathrm{[20],} \mathrm{the} \mathrm{absorption} \mathrm{time} \mathrm{should} \mathrm{be}$ equal to $10 \mathrm{~min}$. Other authors [21,22] have pointed to a longer time (20-30 $\mathrm{min})$. The choice of a not very long period is justified by the study in [23], which concluded that the use of both dry recycled aggregate and aggregate in the state of full saturation worsens the frost resistance of concrete. In [24] it was stated that the use of aggregate soaked in water significantly reduces the water absorbability and sorption of concrete in relation to composites, where superficially dried aggregate was used (without pre-soaking). The latter type of aggregate contributes to a higher porosity of the contact zone of the aggregate-cement paste. Furthermore, the presence of water in aggregate grains is an additional source (as well as classical curing) of water during hydration processes. For this reason the two-stage mixing approach (TSMA) is recommended in [25]; this is an effective way of ensuring stability at the time that the concrete mix is made, and achieving a higher compressive strength and durability of the concrete. Thus, TSMA seems to be the most optimal method, taking into account the conclusions of [23], with a pre-soaking time of about $30 \mathrm{~min}$.

In the context of the mentioned RCA defects and RAC defects, it is particularly important to obtain the firm and tight microstructure of concrete, which is, among other factors, determined by the conditions of its curing. Improperly cured concrete achieves lower quality. Hence, the appropriate curing conditions of RAC seem to be more important than in the case of ordinary concrete, especially because of the different characteristics of their interfacial transition zones [26-28]. However, this does not mean that studies on the influence of curing conditions on the properties of concrete made of natural aggregates have been neglected. One of the most recent studies concerned the effect of curing conditions on the properties of such concretes but produced from alkali-activated cements as binders which enable the reduction of the carbon emissions footprint in comparison with plain Portland cement. Special attention has been focused on the influence of curing conditions on shrinkage, which to some extent determines the durability of concrete $[29,30]$.

The data in the literature concerning the influence of curing conditions on the properties of concrete with waste aggregates, including recycled concrete aggregate, are not numerous, but the results of research conducted with different material assumptions as well as curing conditions may contribute to the knowledge on this subject. In [31], the effects of curing conditions of four types were studied: laboratory curing at $100 \%$ relative humidity $(\mathrm{RH})$ and $20^{\circ} \mathrm{C}$, outdoor natural curing (with a variable temperature and air $\mathrm{RH}$ from $25 \%$ to $88 \%)$, indoor storage $(\mathrm{RH}=45-65 \%)$, and tap water 
storage. After using recycled concrete aggregate at $20 \%, 50 \%$, and $100 \%$ as a substitute for natural aggregate, the 56-day relative (relative to natural aggregate samples) compressive strength decreased slightly with an increase in the amount of recycled aggregate for all curing conditions, except for the case of the curing of concrete samples stored in a chamber with RH equal to $100 \%$. In the case of $100 \%$ RCA, only the external natural conditions of curing contributed to a decrease in strength (by $7 \%$ ). In the case of the modulus of elasticity, its reduction was more related to the increase in the amount of concrete recycled aggregate than to the curing method, although slightly better results were obtained for samples stored in tap water and in a climate chamber with $\mathrm{RH}=100 \%$. Interesting insights have been provided into the curing of recycled aggregate concrete in steam curing, which has proved to have an adverse effect on the compressive strength of concrete. According to [32], steam treatment for $4 \mathrm{~h}$ after concrete mixes were made, combined with subsequent curing in a chamber with a high level of RH ( $>95 \%)$, resulted in a reduction in the 90-day compressive strength of concrete. Although one-day compressive strength proved to be higher by approx. $20 \%$, no difference was observed after 28 days. In turn, thanks to steam curing, the modulus of elasticity of recycled aggregate concrete slightly increased. Such a trend was also observed in the case of splitting tensile strength. The authors of [33] focused on the effects of steam temperature and its application time, conducted on 28-day recycled aggregate concrete, indicating an upper temperature limit for low-pressure brewing at the level of $50{ }^{\circ} \mathrm{C}$ and a steam curing application time of no more than $1 \mathrm{~h}$ in order to avoid the reduction of compressive strength. The application for more than $2 \mathrm{~h}$ significantly reduced the strength.

The strength and durability of concrete, as key parameters determining its quality, depend on the amount of cement, which should be optimized in terms of eco-efficiency. The proposal to optimize the cement content in accordance with the requirements of the designed concrete by taking into account two environmental impact factors when determining the composition of the concrete is related to strength [34]. The binder intensity index $\left(b_{i}\right)$, which expresses the mass of cement per $1 \mathrm{~m} 3$ of concrete necessary to achieve the strength of $1 \mathrm{MPa}\left(\mathrm{kg} / \mathrm{m}^{3} / \mathrm{MPa}\right)$, and the carbon dioxide index $\left(c_{i}\right)$-being expressed as the mass of carbon dioxide emitted during the production process of such a quantity of cement-will allow the achievement of the strength of $1 \mathrm{MPa}(\mathrm{kg} / \mathrm{MPa})$ for the concrete. In both cases, the lowest possible values should be obtained. The optimal solution is to produce concretes of higher strength, because if the compressive strength is higher than $50 \mathrm{MPa}$, the $b_{i}$ coefficient can reach $5 \mathrm{~kg} / \mathrm{m}^{3} / \mathrm{MPa}$, while in low-strength concretes (up to $20 \mathrm{MPa}$ ) $b_{i}$ increases even up to $13 \mathrm{~kg} / \mathrm{m} 3 / \mathrm{MPa}$. For the $c_{i}$ coefficient, the minimum value is assumed at the level of $1.5 \mathrm{~kg} / \mathrm{MPa}$ (in case of using mineral additives in the production of cements), whereas in pure clinker cements it is not possible to achieve a value lower than $4.3 \mathrm{~kg} / \mathrm{MPa}$.

In relation to the above-mentioned approach, according to the authors of this study, the concept of sequestrational carbonation can be introduced, as at the same time the effect of absorbing $\mathrm{CO}_{2}$ from the atmosphere is achieved, which also brings environmental benefits-carbonation closes the $\mathrm{CO}_{2}$ cycle that began with the production of cement. According to [35], $1 \mathrm{~m}^{3}$ of concrete can absorb even more than $100 \mathrm{~kg}$ of $\mathrm{CO}_{2}$. In [36], as part of a life cycle assessment taking into consideration carbonation studies on recycled aggregate, it was stated that per one ton of concrete, from the moment of its crushing, contains $11 \mathrm{~kg}$ of absorbed $\mathrm{CO}_{2}$, which corresponds to the absorption of approximately $25 \mathrm{~kg} \mathrm{CO}_{2}$ per $1 \mathrm{~m}^{3}$ of concrete. This reduces $\mathrm{CO}_{2}$ emission by $5.5 \%$ over the entire life cycle.

The authors of this paper decided to focus on the impact of curing conditions on some properties of recycled aggregate concrete as there has not yet been much research in this area. The problem of water presence in RCA and its technological consequences was taken into account as well. The study was performed in laboratory conditions (at a temperature of $20^{\circ} \mathrm{C}$ and at relative humidity of about $60 \%$ ). The following curing conditions were selected in the laboratory: wet, dry, and protection against water evaporation. Dry conditions are not optimum for the hardening of cement matrix composites. However, they were chosen as the extreme and in order to identify potential differences between their impact and the effect of proper curing conditions. Such an approach was also inspired by comments in [37] on the impact of different hardening conditions on the characteristics of cement matrix composites produced 
with eco-friendly cements. Although studies have referred to cement mortars without fine recycled aggregate, [37] put such emphasis on the relationship between the hardening conditions and the type of cement which manifests even after long periods of hardening, that in the case of the experiment presented in this paper such assumptions of extreme curing conditions were made.

The slump flow and air content of fresh mixes, and the compressive strength, density, and sorption of hardened concretes were determined.

The context of sustainable development was provided not only by the use of recycled concrete aggregate, but also by the use of blast-furnace slag (BFS) cement as a more environmentally friendly binder. At the same time, for comparison purposes, concrete made of Portland cement was also used. Moreover, the eco-efficiency and eco-durability indexes approach was applied to analyze the differences in the influence of curing conditions on the properties of recycled aggregate concretes.

\section{Materials and Methods}

\subsection{Materials}

Two types of cement were used, Portland cement CEM I 42.5R and blast-furnace slag (BFS) cement CEM III/A 42.5N-LH/HSR/NA. Manufacturer of both cements was: Lafarge S.A. Kujawy Cement Plant, Piechcin, Poland. The properties of the binders are given in Table 1.

Table 1. Characteristics of cements used for recycled aggregate concrete (RAC).

\begin{tabular}{ccc}
\hline \multirow{2}{*}{ Characteristic } & \multicolumn{2}{c}{ Cement Type * } \\
& CEM I & CEM III \\
\hline Compressive strength [MPa] after: & & \\
2 days & 29.6 & 14.4 \\
28 days & 56.8 & 52.7 \\
\hline Blaine specific surface $\left[\mathrm{m}^{2} / \mathrm{kg}\right]$ & 387 & 467 \\
Ignition loss [\%] & 3.2 & 0.7 \\
Insoluble parts [\%] & 0.9 & 0.3 \\
\hline $\mathrm{SO}_{3}[\%]$ & 2.7 & 2.2 \\
$\mathrm{Cl}^{-}[\%]$ & 0.07 & 0.07 \\
$\mathrm{Al}_{2} \mathrm{O}_{3}[\%]$ & 5.2 & 7.65 \\
$\mathrm{Na}_{2} \mathrm{O}$ eq [\%] & 0.61 & 0.7 \\
$\mathrm{MgO}_{0}$ [\%] & 1.2 & 1.4 \\
\hline $\mathrm{C}_{3} \mathrm{~S}[\%]$ & 54.4 & 28.3 \\
$\mathrm{C}_{3} \mathrm{~A}[\%]$ & 8.9 & 3.7 \\
\hline
\end{tabular}

* specifically: CEM I 42.5R and CEM III/A 42.5N-HSR/NA.

Tap water (in accordance with the European standard EN-1008:2002 was applied for producing concrete mixes [38].

The highly effective fluidifying admixture of a new-generation polycarboxylate ether superplasticizer was chosen for the concrete mixes in order to improve workability. The properties of the admixture were as follows: $\mathrm{pH}-6$, specific density $-1.07 \mathrm{~kg} / \mathrm{dm}^{3}$, solid content $-30 \%, \mathrm{NaO}_{\text {eq }}<0.8 \%$.

Two types of aggregate-natural (sand and gravel) coming from local sources and recycled concrete aggregate-were applied. The latter was prepared about 6 years before the beginning of the experiment by crushing three parent concretes with three different water-to-cement ratios. A laboratory jaw crusher was used for crushing. Next, the aggregate was separated on screens into fractions $(4 / 6$, $6 / 8,8 / 12$, and $12 / 16 \mathrm{~mm}$ ) and placed in open boxes, located outside the building. A long storage period in variable thermal and moisture conditions contributed to the carbonation of the aggregate.

The recipes and compressive strength of the parent concretes (PC) are given in Table 2 . The recycled concrete aggregate (RCA) resulted from the mix of these three parent concretes, and was applied for the 
investigations as $0 \%, 50 \%$ and $100 \%$ replacements of natural coarse aggregate. The final sieve curves of natural and recycled concrete aggregate compositions used in the experiment are presented in Figure 1.

Table 2. Recipes and average compressive strength of parent concretes (PC).

\begin{tabular}{ccccc}
\hline Constituent & Unit & PC_1 & PC_2 & PC_3 \\
\hline CEM I 42,5 N-HSR/NA & {$\left[\mathrm{kg} / \mathrm{m}^{3}\right]$} & 329 & 284 & 240 \\
Water & {$\left[\mathrm{kg} / \mathrm{m}^{3}\right]$} & 148 & 156 & 156 \\
w/c ratio & {$[-]$} & 0.45 & 0.55 & 0.65 \\
\hline Sand 0/2 mm & {$\left[\mathrm{kg} / \mathrm{m}^{3}\right]$} & 646 & 645 & 649 \\
Gravel 2/8 mm & {$\left[\mathrm{kg} / \mathrm{m}^{3}\right]$} & 804 & 814 & 834 \\
Gravel 8/16 mm & {$\left[\mathrm{kg} / \mathrm{m}^{3}\right]$} & 536 & 543 & 556 \\
\hline 60-d compressive strength * & {$[\mathrm{MPa}]$} & 61.8 & 45.2 & 36.8 \\
\hline
\end{tabular}

${ }^{*}$ measured before crushing into aggregate.

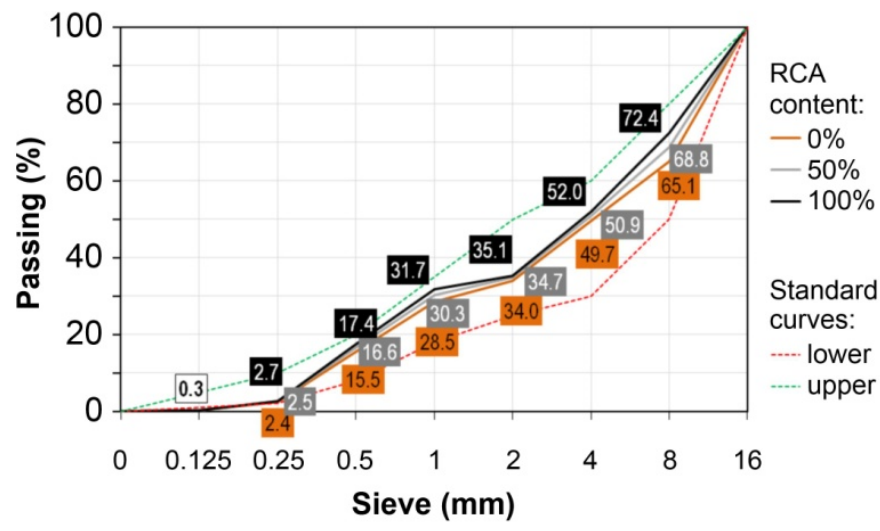

Figure 1. Final sieve curves of aggregate mixes.

\subsection{Methods}

2.2.1. Granulometric Analysis of Aggregate

Granulometric analysis conformed to the European standard EN-933-2:1999 [39].

2.2.2. Water Absorption of Recycled Concrete Aggregate

Measurements referring to each fraction of RCA were realized according to the following procedure:

- $\quad$ preparing aggregate samples (for each fraction: $4 / 6,6 / 8,8 / 12$, and 12/16 mm) and weighing them using scales,

- putting the aggregate into small buckets,

- $\quad$ adding water to each bucket with an aggregate sample,

- waiting for $2 \mathrm{~h}$ in order to pre-soak the aggregate samples in water,

- $\quad$ removing aggregate samples from the bucket (using a sieve) and placing them on a towel for drying,

- waiting until the surface of aggregate was still in a wet state but without a visible layer of water on the grains' surface,

- $\quad$ rotating the grains of aggregate in order to ease the evaporation of the surface layer of water,

- weighing the aggregate in wet state.

Before the measurement of water absorption the RCA was superficially dried by keeping it at a relative humidity of $50-60 \%$ for 2 weeks. The results of the water absorption measurements of the recycled concrete aggregate are presented in Table 3. 
Table 3. Water absorption of recycled concrete aggregate (RCA).

\begin{tabular}{cccc}
\hline \multirow{2}{*}{$\begin{array}{c}\text { Fraction } \\
(\mathbf{m m})\end{array}$} & \multicolumn{2}{c}{ Mass of Aggregate $(\mathrm{g})$} & Water Absorption \\
\cline { 2 - 4 } & Dry State & Wet State & $\mathbf{( \% )}$ \\
\hline $4 / 6$ & 400 & 411.3 & 2.8 \\
$6 / 8$ & 600 & 614.2 & 2.4 \\
$8 / 12$ & 800 & 823.6 & 3.0 \\
$12 / 16$ & 1200 & 1228 & 2.3 \\
\hline
\end{tabular}

\subsubsection{Concrete Recipes}

The concrete recipes applied in the experiment are presented in Table 4.

Table 4. Recipes for the RAC series.

\begin{tabular}{ccccc}
\hline Constituent & Unit & $\mathbf{0 \%}$ RCA & $\mathbf{5 0 \%}$ RCA & $\mathbf{1 0 0 \%}$ RCA \\
\hline Cement (CEM I or & $\left(\mathrm{kg} / \mathrm{m}^{3}\right)$ & 386 & 386 & 386 \\
CEM III) & $(\%$ of CEM) & 0.2 & 0.2 & 0.2 \\
Superplasticiser & $(-)$ & 0.45 & 0.45 & 0.45 \\
$w / c$ & 175 & 175 & 175 \\
Water & $\left(\mathrm{kg} / \mathrm{m}^{3}\right)$ & 0 & 11.5 & 23.0 \\
W $_{\text {abs }}^{*}$ & & 175 & 186.5 & 198 \\
W (total) & & 577 & 616 & 648 \\
Sand 0/2 mm & & 0 & 137 & 278 \\
Natural 2/4 mm & $\left(\mathrm{kg} / \mathrm{m}^{3}\right)$ & 636 & 316 & 0 \\
Gravel 2/8 mm & & 636 & 316 & 0 \\
Gravel 8/16 mm & & 0 & 93 & 184 \\
\hline RCA 4/6 mm & & 0 & 79 & 157 \\
RCA 6/8 mm & $\left(\mathrm{kg} / \mathrm{m}^{3}\right)$ & 0 & 139 & 278 \\
RCA 8/12 mm & & 0 & 101 & 202 \\
RCA 12/16 mm & & &
\end{tabular}

$\mathrm{w} / \mathrm{c}$ - water to cement ratio; $\mathrm{W}_{\mathrm{abs}}{ }^{*}$ - additional water needed as the result of RCA absorbability; $\mathrm{W}$ - total amount of water.

\subsubsection{Manufacturing Concrete Mixes}

The components of concretes were mixed using a paddle-type $0.05 \mathrm{~m}^{3}$ mixer. Mixes were prepared using the two-stage mixing approach proposed by [23]. The approach involves adding $50 \%$ of water (which was calculated according to the mass of the total amount of aggregate) to the aggregate and leaving it for $30 \mathrm{~min}$ to saturate, while the remaining water is added in a traditional way. According to the authors, such a method significantly improves concrete quality. After a $30 \mathrm{~min}$ break, cement was added and the composition was mixed for a $60 \mathrm{~s}$ period. Then the remaining water and the total amount of superplasticizer were added and mixed for a 3 min period.

\subsubsection{Properties of Concrete Mixes}

The slump of concrete mix was measured according to the method specified in the European standard EN 12350-2:2009 [40]. The air content in fresh concrete was tested according to the method specified in EN 12350-7:2009 [41].

\subsubsection{Properties of Hardened Concretes}

Compressive strength tests were conducted on $100 \mathrm{~mm}$ cubic samples. After demolding, the samples were divided into three groups and subjected to three different conditions of hardening until the time of testing came: in a curing chamber at $\mathrm{RH}>95 \%$ and $20{ }^{\circ} \mathrm{C}$ (wet conditions), in a sheltered space at RH $50-60 \%$ and $20{ }^{\circ} \mathrm{C}$ (dry conditions), and protected against drying (preventing 
water evaporation) under foil at $20^{\circ} \mathrm{C}$ (PEV conditions). The number of samples for each examined series of concrete was five. The obtained results were recalculated for the case of $150 \mathrm{~mm}$ cubic samples and these were analyzed further. The testing of compressive strength was carried out according to the European standard EN 12350-3:2009 [42].

The testing of sorption as a useful parameter for the assessment of concrete durability has been proposed in [43], among others, and alternatively in European standard EN 13057:2002 [44]. Sorption was conducted on $100 \mathrm{~mm}$ diameter cylindrical samples. The number of samples for each examined series of concrete was four. Each sample was dried at $50{ }^{\circ} \mathrm{C}$ for 5 days in the laboratory dryer. In the subsequent stage they were put onto a plastic mesh to allow for free water capillary sorption on the entire base surface without direct contact with the container bottom. The water level was equal to $1 / 5$ of the sample height. Figure 2 shows the samples during the sorption test. Measurements were performed after 1, 5, 10, 20, 40, 60, and $75 \mathrm{~min}$ in order to evaluate the rate of sorption. Calculations of saturated water sorption (S) were done according to Formula (1) given below [43]:

$$
S=\left(\frac{\Delta M_{t}}{\sqrt{t}}\right) \cdot\left(\frac{d}{M_{s a t}-M_{o}}\right)
$$

where $S$ is sorptivity $\left(\mathrm{mm} / \mathrm{h}^{0.5}\right) ; \Delta M$ —change of mass with respect to dry mass (g); $M_{\text {sat }}$ —saturated mass of concrete (g); $M_{0}$ —dry mass of concrete (g); $d$-sample thickness (mm); $t$-period of absorption (h).

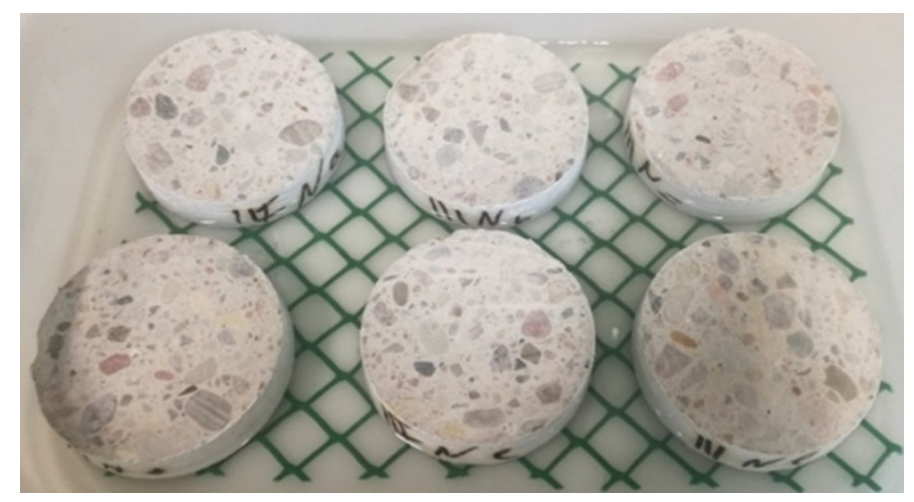

Figure 2. Concrete samples during sorption test.

At regular time intervals the mass of absorbed water was determined using a balance. Measurements were terminated after $75 \mathrm{~min}$ and the specimens were then vacuum-saturated and soaked in water in order to determine the effective porosity. Plotting the mass of water absorbed against the square root of time gives a linear relationship. The sorptivity of concrete can be calculated from the slope of the straight line plot. According to [33], the acceptable limit is $<9 \mathrm{~mm} / \mathrm{h}^{0.5}\left(<6 \mathrm{~mm} / \mathrm{h}^{0.5}\right.$ for laboratory conditions).

The saturation degree $\left(s d_{i}\right)$ was determined using the results of the sorption test (based on the difference between the weight of saturated samples and samples dried at $50{ }^{\circ} \mathrm{C}$ for 5 days) according to Formula (2) [43]:

$$
s d_{i}=\left(\frac{M_{s a t}-M_{o}}{M_{o}}\right) \cdot 100 \%
$$

where $M_{\text {sat }}$ is saturated mass of concrete (g) and $M_{o}$ mass of concrete sample dried at $50{ }^{\circ} \mathrm{C}(\mathrm{g})$.

\subsubsection{Eco-Efficiency and Eco-Durability Indexes}

The average emission value of CEM I cement taken from the calculation of $b_{i}$ and $c_{i}$ [32] is $761 \mathrm{~kg} \mathrm{CO} /$ ton while that of CEM III is $360 \mathrm{~kg} \mathrm{CO}_{2} /$ ton (data from production in a Polish cement plant). Furthermore, for the CEM III series, the $c_{i}$ coefficient was also calculated in an alternative 
configuration, i.e., taking into consideration emissions associated with the production of ground granulated blast-furnace slag (143 $\mathrm{kg} \mathrm{CO} /$ ton-according to [2]).

The authors of this paper used a method proposed in [33] and described in Section 2.2.6 as the basis for the determination of eco-durability $\left(\mathrm{S}-\mathrm{CO}_{2}\right.$ index). This is used to determine one of the three so-called durability indices (i.e., sorption), along with the oxygen permeability index (OPI) and chloride conductivity (CC). The calculation of the proposed $\mathrm{S}-\mathrm{CO}_{2}$ index should be performed in accordance with Formula (3):

$$
S-\mathrm{CO}_{2}=\frac{1}{E_{\mathrm{CO}_{2}} \cdot S}
$$

where $E_{\mathrm{CO} 2}-\mathrm{CO}_{2}$ mass emitted to obtain $1 \mathrm{~m}^{3}$ of concrete $\left(\mathrm{t} / \mathrm{m}^{3}\right)$ and $S$ - sorptivity $\left(\mathrm{mm} / \mathrm{h}^{0.5}\right)$. Higher index values indicate higher eco-durability.

\subsubsection{ANOVA and Tukey's Test}

Analysis of variance (ANOVA) was performed for density and compressive strength results. Additionally, differences were checked using Tukey's post-hoc test at a $95 \%$ confidence level $($ alpha $=0.05)$. Statistical calculations were performed using Statistica software, licence no. JPZ612B037802AR-P. (Poznań University of Life Sciences, Poznań, Poland).

\section{Results and Discussion}

\subsection{Fresh Mix Properties}

The slump and air content measurements for concrete mixes made of CEM I and CEM III in relation to RCA content are presented in Table 5. The slump of concrete mix CEM I with 100\% RCA content was the lowest and a significant loss of workability compared to concrete mixes made of CEM III was observed, while at $0 \%$ and 50\% RCA the results of slump measurements are similar in both cases. Possibly, the differences are due to different compatibility between cement and the superplasticiser for each type of cement.

Table 5. Slump and air content of RAC mixes.

\begin{tabular}{cccc}
\hline $\begin{array}{c}\text { Cement } \\
\text { Type }\end{array}$ & $\begin{array}{c}\text { RCA Content } \\
(\mathbf{\%})\end{array}$ & $\begin{array}{c}\text { Slump } \\
(\mathbf{m m})\end{array}$ & $\begin{array}{c}\text { Air Content } \\
\mathbf{( \% )}\end{array}$ \\
\hline CEM I & 0 & 135 & 3.6 \\
& 50 & 150 & 4.4 \\
& 100 & 58 & 3.8 \\
\hline CEM III & 0 & 165 & 2.8 \\
& 50 & 130 & 4.3 \\
& 100 & 120 & 4.9 \\
\hline
\end{tabular}

Additionally, the air content results show that more RCA content results in higher air content. This is clearly linked to the presence of air pores in the structure of the recycled aggregate. However, the differences are not significant, which can be justified by the use of carbonated aggregate, which has a lower porosity than material obtained immediately after crushing.

\subsection{Density}

The density of concretes made of CEM I and CEM III after 90 days of hardening in relation to RCA content is presented in Figure 3. Density was slightly higher for RCA concrete series made of both CEM I and CEM III in the case of wet conditions of hardening compared with dry conditions of curing. The trend affected both $0 \%$ and 50\% RCA. However, concretes including 100\% RCA presented similar densities in the case of both wet and PEV conditions. 

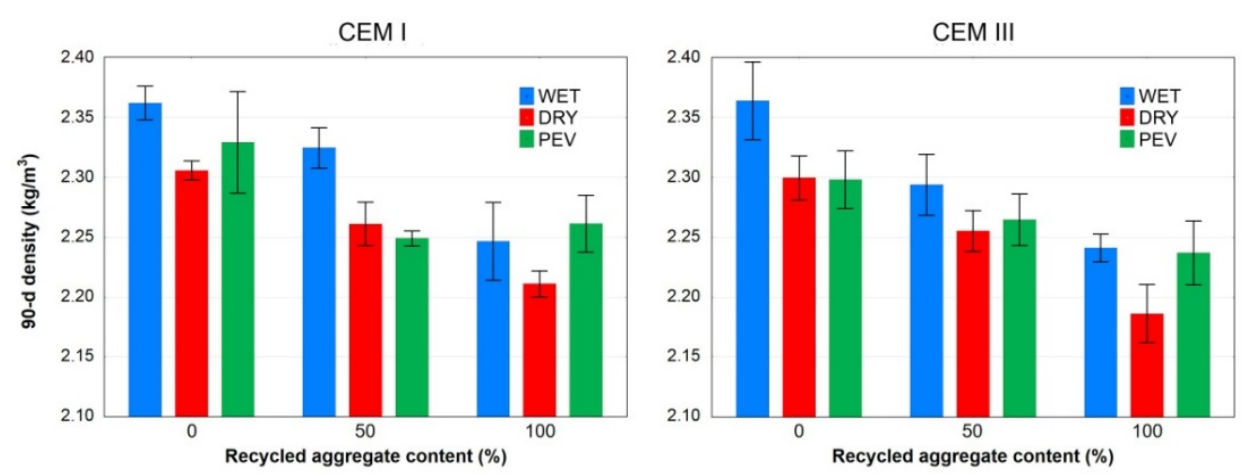

Figure 3. Average density of 90-day concrete.

\subsection{Compressive Strength}

The compressive strength results of concretes made of CEM I and CEM III after both 28 and 90 days in relation to RCA content are presented in Figure 4. Compressive strength differences calculated on the base of 28- and 90-day results are shown in Figure 5. The results of Tukey's post-hoc test for 90-day strength are presented in Table 6 . Wet conditions of hardening were better for concretes made of both CEM I and CEM III, but after 90 days they were more effective in the case of CEM I used as a binder. PEV can be observed to be a more effective way of curing for both cements in the case of $0 \%$ and $100 \%$ RCA, while less effective is the influence on the compressive strength of concrete with $50 \%$ RCA. Probably, the amount of water delivered during pre-soaking for samples with 50\% RCA is not sufficient to prevent water consumption during hydration processes. After some time, the water no longer reaches the paste from the outside or from the recycled aggregate. In such a situation, the process of hydration for samples treated with PEV seems to be similar to the process of hydration for samples treated under wet conditions-with a water deficit, which contributes to lower strength. On the other hand, increasing the share of water from pre-soaking in the series with $100 \%$ RCA (from 11 to $22 \mathrm{~kg} / \mathrm{m}^{3}$ ) eliminates this unfavorable effect.
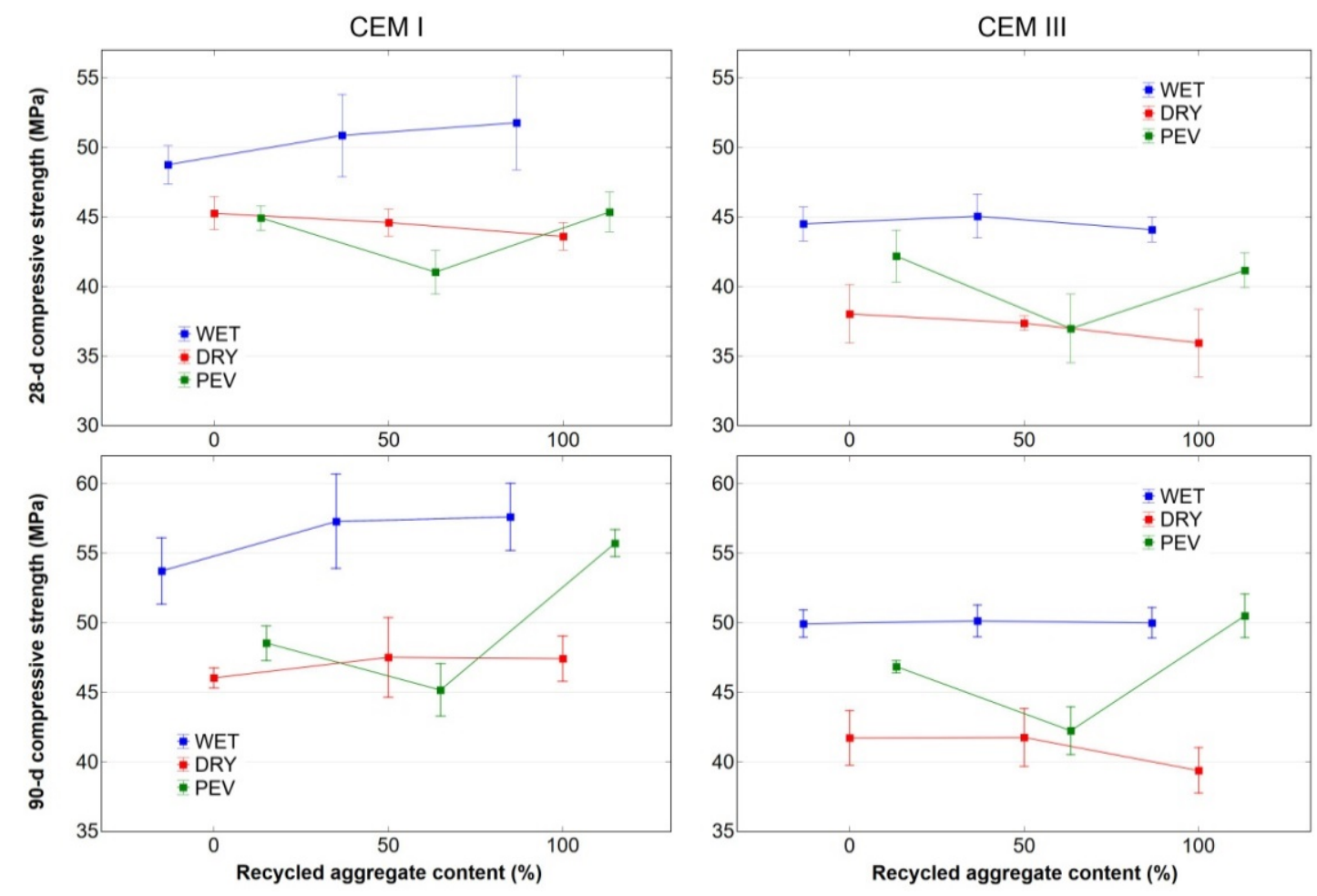

Figure 4. Compressive strength of concrete after 28 and 90 days. 

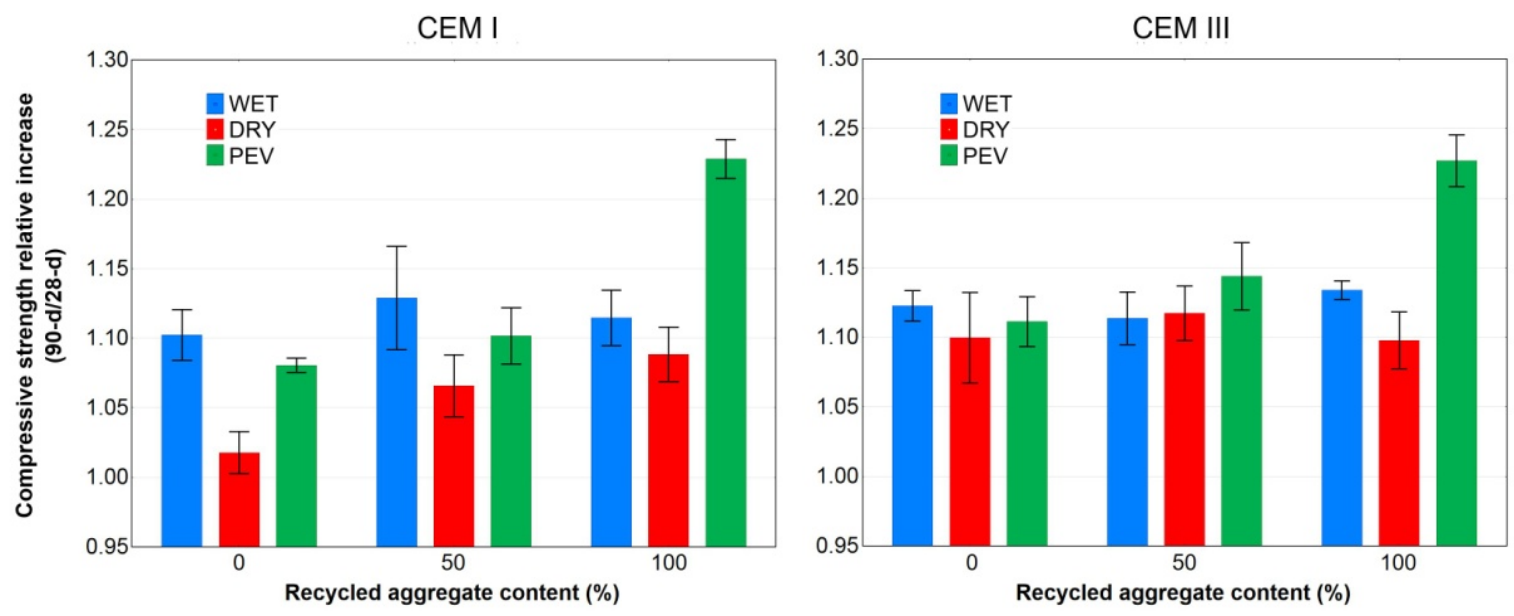

Figure 5. Compressive strength increase between 28 and 90 days.

Table 6. Tukey's test results for 90 -day compressive strength $\left(f_{c} 90-d\right)$ of RAC series.

\begin{tabular}{|c|c|c|c|c|c|c|c|c|c|c|c|}
\hline \multirow{2}{*}{$\begin{array}{l}\text { Cement } \\
\text { Type }\end{array}$} & \multirow{2}{*}{$\begin{array}{c}\text { RCA } \\
(\%)\end{array}$} & \multirow{2}{*}{ Curing Conditions } & \multirow{2}{*}{$\begin{array}{c}\mathrm{f}_{\mathrm{c}} 90-\mathrm{d} \\
(\mathrm{MPa})\end{array}$} & \multicolumn{8}{|c|}{ Homogenous Groups } \\
\hline & & & & 1 & 2 & 3 & 4 & 5 & 6 & 7 & 8 \\
\hline III & 100 & Dry & 39.4 & $* * *$ & & & & & & & \\
\hline III & 0 & Dry & 41.8 & $* * *$ & $* * *$ & & & & & & \\
\hline III & 50 & Dry & 41.8 & $* * *$ & $* * *$ & & & & & & \\
\hline III & 50 & PEV & 42.3 & $* * *$ & $* * *$ & & & & & & \\
\hline $\mathrm{I}$ & 50 & PEV & 45.2 & & $* * *$ & $* * *$ & & & & & \\
\hline I & 0 & Dry & 46.1 & & & $* * *$ & & & & & \\
\hline III & 0 & PEV & 46.9 & & & $* * *$ & $* * *$ & & & & \\
\hline I & 100 & Dry & 47.5 & & & $* * *$ & $* * *$ & $* * *$ & & & \\
\hline I & 50 & Dry & 47.6 & & & $* * *$ & $* * *$ & $* * *$ & & & \\
\hline I & 0 & PEV & 48.5 & & & $* * *$ & $* * *$ & $* * *$ & & & \\
\hline III & 0 & Wet & 50.0 & & & & $* * *$ & $* * *$ & & & \\
\hline III & 100 & Wet & 50.0 & & & & $* * *$ & $* * *$ & & & \\
\hline III & 50 & Wet & 50.2 & & & & $* * *$ & $* * *$ & & & \\
\hline III & 100 & PEV & 50.5 & & & & & $* * *$ & $* * *$ & & \\
\hline I & 0 & Wet & 53.7 & & & & & & $* * *$ & $* * *$ & \\
\hline I & 100 & PEV & 55.7 & & & & & & & $* * *$ & $* * *$ \\
\hline I & 50 & Wet & 57.3 & & & & & & & & $* * *$ \\
\hline I & 100 & Wet & 57.6 & & & & & & & & $* * *$ \\
\hline
\end{tabular}

alpha (significance level of the error) $=0.05$; MS (Mean Square) Error $=2.1118$.

Dry conditions of hardening turn out to be more hazardous for the compressive strength of concretes made of CEM III than for those made of CEM I. Statistically, wet conditions of hardening made compressive strength higher (the strength of samples of all six series treated under wet conditions exceeded the value of $50 \mathrm{MPa}$ ), while dry conditions made the compressive strength lower. In samples with a $100 \%$ level of recycled concrete aggregate, there was a similar 90-day compressive strength for concrete cured with the use of PEV and for concrete cured in water with both cements applied as binders (both series of concretes treated with the PEV method and with 100\% RCA constituted one homogeneous group with the corresponding series of concretes of the wet group with $50 \%$ and $100 \%$ RCA). This effect is connected with the internal curing (self-curing) process, because of the bigger (than for $50 \% \mathrm{RCA}$ ) amount of water taken up by RCA during the pre-soaking procedure.

\subsection{Sorption}

The sorption results of concretes made of CEM I and CEM III in relation to RCA content are presented in Figure 6. The wet conditions of hardening and the PEV way of curing were more suitable for concretes made of both CEM I and CEM III. In the case of CEM I as a binder, all conditions of hardening had more similar influence on sorption in comparison with CEM III. For CEM III used 
as a binder, dry curing conditions were more hazardous compared to CEM I, but on the other hand wet curing conditions were slightly better for CEM III. The lower sorption for concrete made of blast-furnace slag cement followed its denser microstructure due to using just this binder, but only under the condition of proper curing (wet or PEV). The dry way of curing should be definitively excluded, which has been confirmed by [31].
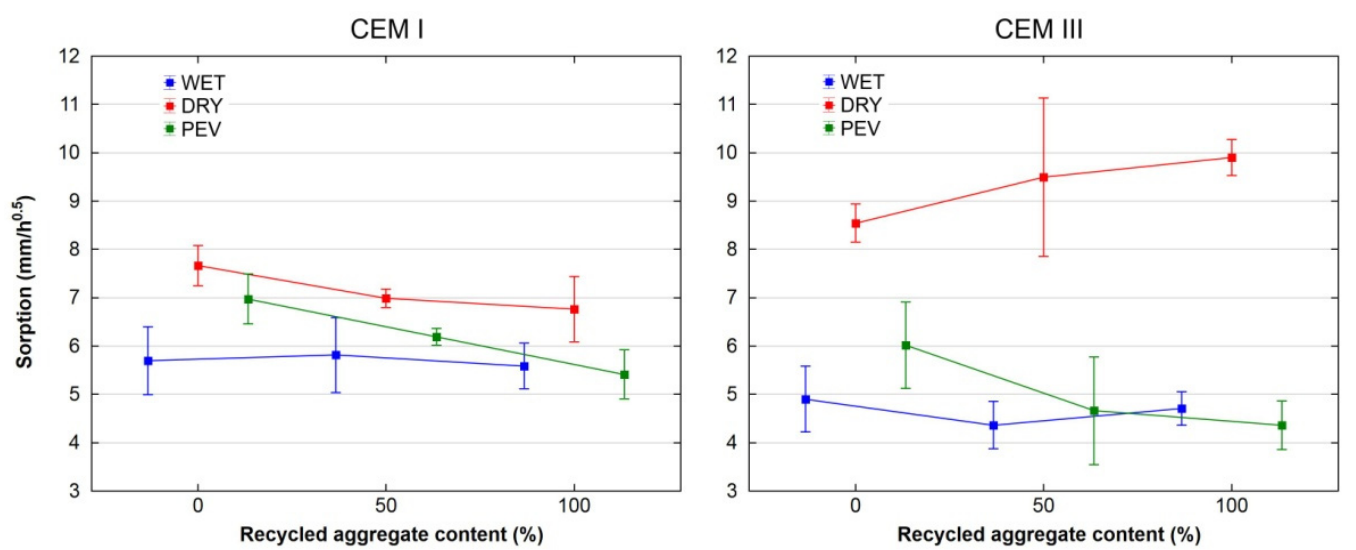

Figure 6. Sorption of concrete.

\subsection{Saturation Degree}

The saturation degree of concretes made of CEM I and CEM III in relation to RCA content is presented in Figure 7. Wet curing conditions were more suitable for concrete made of both CEM I and CEM III. Moreover, CEM III was shown to be more susceptible to dry curing conditions than CEM I.

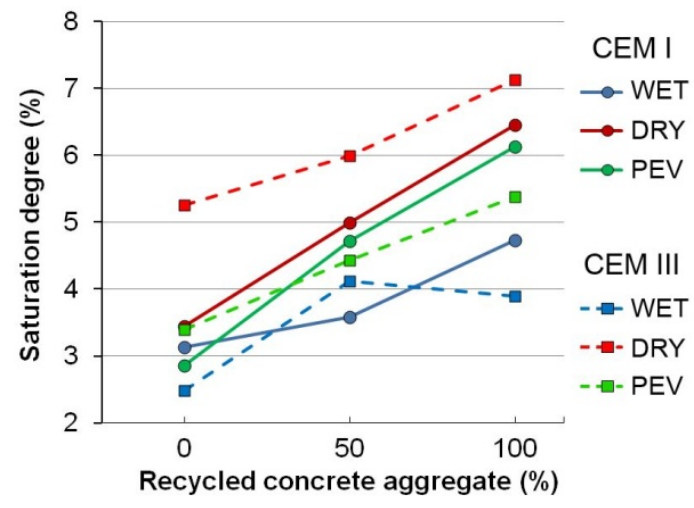

Figure 7. Saturation degree of concrete.

\subsection{Eco-Efficiency and Eco-Durability Indexes}

The values of $b_{i}, c_{i}$, and the S- $\mathrm{CO}_{2}$ index are presented in Table 7. The highest, i.e., the least favorable, $b_{i}$ values were obtained mainly for concrete treated under dry conditions, and the lowest under wet conditions (in both cases regardless of the RCA) and with 100\% RCA under PEV conditions. Higher $b_{i}$ values were obtained for CEM III, which resulted from the lower strength of the series with this cement. The $b_{i}$ index value should be treated as supplementary information, which indicates both the quality of cement and the conditions of concrete curing. From the point of view of $\mathrm{CO}_{2}$ emission during the cement production process, the more significant eco-efficiency coefficient is $c_{i}$. The calculations show that $c_{i}$ index values were more favorable for CEM III due to the use of granulated blast-furnace slag (BFS cement), which constituted approximately $50 \%$ of the composition, and the best results were obtained for the series treated under wet conditions. Only slightly higher were the values of the $c_{i}$ coefficient when emissions associated with the production of ground granulated blast-furnace slag were taken into consideration. When considering the $\mathrm{S}-\mathrm{CO}_{2}$ index, the use of CEM III 
cement, regardless of whether the $\mathrm{CO}_{2}$ emissions associated with the production of ground granulated blast-furnace slag are taken into account or not, is more advantageous.

Table 7. Indexes of eco-efficiency-binder intensity, $b_{i}\left(\mathrm{~kg} / \mathrm{m}^{3} / \mathrm{MPa}\right)$ and carbon dioxide, $c_{i}$ $(\mathrm{kg} / \mathrm{MPa})$-and eco-durability, S-CO $2\left(1 /\left(\mathrm{t}_{\mathrm{CO} 2} / \mathrm{m}^{3} \cdot \mathrm{mm} / \mathrm{h}^{0.5}\right)\right.$.

\begin{tabular}{|c|c|c|c|c|c|c|c|c|c|c|}
\hline \multirow{3}{*}{$\begin{array}{c}\text { Cement } \\
\text { Type }\end{array}$} & \multirow{3}{*}{$\begin{array}{c}\text { RCA } \\
\text { Content } \\
(\%)\end{array}$} & \multicolumn{9}{|c|}{ Curing Conditions } \\
\hline & & \multicolumn{3}{|c|}{ Wet } & \multicolumn{3}{|c|}{ Dry } & \multicolumn{3}{|c|}{ PEV } \\
\hline & & $b_{i}$ & $c_{i}$ & $\mathrm{~S}-\mathrm{CO}_{2}$ & $b_{i}$ & $c_{i}$ & $\mathrm{~S}-\mathrm{CO}_{2}$ & $b_{i}$ & $c_{i}$ & $\mathrm{~S}-\mathrm{CO}_{2}$ \\
\hline \multirow[t]{3}{*}{ CEM I } & 0 & 7.2 & 5.5 & 0.231 & 8.4 & 6.4 & 0.172 & 8.0 & 6.0 & 0.189 \\
\hline & 50 & 6.7 & 5.1 & 0.226 & 8.1 & 6.4 & 0.188 & 8.5 & 6.5 & 0.212 \\
\hline & 100 & 6.7 & 5.1 & 0.201 & 8.1 & 6.2 & 0.204 & 6.9 & 5.3 & 0.249 \\
\hline \multirow{3}{*}{ CEM III * } & 0 & 7.7 & 2.8 & 0.567 & 9.3 & 3.3 & 0.325 & 8.2 & 3.0 & 0.462 \\
\hline & 50 & 7.7 & 2.8 & 0.636 & 9.3 & 3.3 & 0.293 & 9.1 & 3.3 & 0.596 \\
\hline & 100 & 7.7 & 2.8 & 0.590 & 9.8 & 3.5 & 0.280 & 7.6 & 2.8 & 0.637 \\
\hline \multirow[t]{3}{*}{ CEM III ** } & 0 & & 3.0 & 0.526 & & 3.6 & 0.302 & & 3.2 & 0.428 \\
\hline & 50 & & 3.0 & 0.590 & & 3.6 & 0.270 & & 3.5 & 0.553 \\
\hline & 100 & & 3.0 & 0.547 & & 3.8 & 0.260 & & 3.0 & 0.591 \\
\hline
\end{tabular}

*- taking into account only emissions of $\mathrm{CO}_{2}$ resulting only from cement production. ${ }^{* *}$-taking into account emissions of $\mathrm{CO}_{2}$ resulting from the production of cement and ground granulated blast-furnace slag.

\section{Conclusions}

Based on the obtained results the following conclusions have been formulated:

1. Concrete mix made of CEM I turned out to be more sensitive to slump loss at the maximal content of RCA in comparison to concrete mix with blast-furnace slag cement as a binder. However, the worst influence of RCA presence on air content in concrete mix occurred when blast-furnace slag cement was used.

2. Dry conditions of hardening were perceived as more hazardous for compressive strength in the case of concretes made of both CEM I and CEM III cement.

3. Protection against drying (water evaporation) can be more sufficient for concrete with high amounts of RCA than for ordinary concrete, taking into account compressive strength and in comparison to wet conditions of curing.

4. Statistical analysis showed that the influence of RCA participation on compressive strength was less meaningful than the way of curing for two opposite conditions (wet and dry).

5. The conditions of hardening influenced the sorption of concrete, being definitely better for wet curing and with protection against drying (water evaporation) and in both cases better for CEM III than CEM I as a binder.

6. The binder intensity index $b_{i}$ was slightly higher for CEM III than CEM I. However, the carbon dioxide emission index $c_{i}$ was better in cases where blast-furnace slag cement was used as a binder.

7. In terms of durability, the authors of this paper propose the eco-durability index $\mathrm{S}-\mathrm{CO}_{2}$, especially for composites with recycled aggregate. In the conducted research, more favorable values of this index were obtained for concrete with blast-furnace slag cement, but under the condition of proper curing.

In summary, it is worth mentioning that the authors plan to develop studies, extend their objectives and conditions, and use more sophisticated methods. The paper presented in its current form provides a certain contribution, which is expected by the authors to provide some knowledge and inspire other research.

Author Contributions: Conceptualization (A.M.G., D.Z.); data curation (D.Z., W.A.R.); formal analysis (A.M.G., W.A.R.); investigation (D.Z., W.A.R.); methodology (A.M.G., D.Z., W.A.R.); resources (A.M.G., W.A.R.); software 
D.Z.); visualization (D.Z., W.A.R.); writing—original draft (A.M.G., D.Z., W.A.R.); writing—review \& editing (A.M.G.), supervision (A.M.G.). All authors have read and agreed to the published version of the manuscript.

Funding: This research received no external funding.

Conflicts of Interest: The authors declare no conflict of interest.

\section{References}

1. Andrew, R.M. Global $\mathrm{CO}_{2}$ emissions from cement production. Earth Syst. Sci. Data. 2018, 10, $2213-2239$. [CrossRef]

2. Flower, D.J.; Sanjayan, J.G. Greenhouse Gas Emissions Due to Concrete Manufacture. In Handbook of Low Carbon Concrete; Nazari, A., Sanjayan, J.G., Eds.; Elsevier: Oxford, UK, 2017; Chapter 1; pp. 1-16. [CrossRef]

3. Pawluczuk, E.; Kalinowska-Wichrowska, K. Ocena zastosowania spoiwa z recyklingu do betonów drobnoziarnistych. Civ. Environ. 2015, 6, 193-200.

4. Pawluczuk, E.; Kozak, K. Wpływ stosowania drobnego kruszywa z recyklingu na wybrane właściwości kompozytów cementowych. Civ. Environ. 2016, 7, 39-45.

5. Zhao, Z.; Remond, S.; Damidot, D.; Xu, W. Influence of fine recycled concrete aggregates on the properties of mortars. Constr. Build. Mater. 2015, 8, 179-186. [CrossRef]

6. Yacoub, A.; Djerbi, A.; Fen-Chong, T. Water absorption in recycled sand: New experimental methods to estimate the water saturation degree and kinetic filling during mortar mixing. Constr. Build. Mater. 2018, 158, 464-471. [CrossRef]

7. Shima, H.; Tateyashiki, H.; Matsuhashi, R.; Yoshida, Y. An advanced concrete recycling technology and its applicability assessment through input-output analysis. J. Adv. Concr. Technol. 2005, 6, 53-67. [CrossRef]

8. Pawluczuk, E.; Kalinowska-Wichrowska, K.; Bołtryk, M.; Jiménez, J.R.; Fernández, J.M. The influence of heat and mechanical treatment of concrete rubble on the properties of recycled aggregate concrete. Materials 2019, 12, 367. [CrossRef]

9. Katz, A. Treatments for the improvement of recycled aggregate. J. Mater. Civ. Eng. 2004, 16, 597-603. [CrossRef]

10. Kim, H.S.; Kim, B.; Kim, K.S.; Kim, J.M. Quality improvement of recycled aggregates using the acid treatment method and the strength characteristics of the resulting mortar. J. Mater. Cycles Waste Manag. 2017, 19, 968-976. [CrossRef]

11. Grabiec, A.M.; Klama, J.; Zawal, D.; Krupa, D. Modification of recycled concreteaggregate by calcium carbonate biodeposition. Constr. Build. Mater. 2012, 34, 145-150. [CrossRef]

12. Qiu, J.; Tng, D.Q.S.; Yang, E.H. Surface treatment of recycled concrete aggregatesthrough microbial carbonate precipitation. Constr. Buid. Mater. 2014, 57, 144-150. [CrossRef]

13. Tam, V.W.Y.; Butera, A.; Le, K.N. Carbon-conditioned recycled aggregate in concreteproduction. J. Clean. Prod. 2016, 13, 672-680. [CrossRef]

14. Li, L.; Poon, C.S.; Xiao, J.; Xuan, D. Effect of carbonated recycled coarse aggregate onthe dynamic compressive behavior of recycled aggregate concrete. Constr. Build. Mater. 2017, 151, 52-62. [CrossRef]

15. Xiao, J. Modification of Modeled Recycled Aggregate Concrete by Carbonation. In Recycled Aggregate Concrete Structures; Springer: Berlin, Germany, 2017; pp. 115-124. ISBN 978-3-662-53985-9.

16. Thomas, B.S.; Gupta, R.C.; Panicker, V.J. Recycling of waste tire rubber as aggregate in concrete: Durability-related performance. J. Clean. Prod. 2016, 112, 504-513. [CrossRef]

17. Montero, J.; Laserna, S. Influence of effective mixing water in recycled concrete. Constr. Build. Mater. 2017, 132, 343-352. [CrossRef]

18. Tam, V.W.Y.; Gao, X.F.; Tam, C.M.; Chan, C.H. New approach in measuring water absorption of recycled aggregates. Constr. Build. Mater. 2008, 22, 364-369. [CrossRef]

19. Ferreira, L.; de Brito, J.; Barra, M. Influence of the pre-saturation of recycled coarse concrete aggregates on concrete properties. Mag. Concr. Res. 2013, 63, 617-627. [CrossRef]

20. Maultzsch, M. Wykorzystanie Przetworzonego Gruzu Budowlanego-Przyczynek Do Zrównoważonego Rozwoju Technologii Betonu; Dni Betonu: Szczyrk, Poland, 2002.

21. Dworzańczyk-Krzywiec, D. Wpływ zawartości kruszywa z recyklingu na wybrane właściwości betonów. Civ. Environ. Eng. 2011, 2, 229-233. 
22. Gołda, A.; Giergiczny, Z. Popiół lotny składnikiem betonu zawierającego kruszywa z odzysku gruzu betonowego. Cem. Wapno Beton 2007, 12, 201-206.

23. De Oliveira, M.B.; Vazquez, E. The influence of retained moisture in aggregates from recycling on the properties of new hardened concrete. Waste Manag. 1996, 16, 113-117. [CrossRef]

24. Pawluczuk, E. Kształtowanie strefy kontaktowej kruszywo-zaczyn w betonach recyklingowych. Bud. Inżynieria Środowiska 2011, 2, 369-376.

25. Tam, V.W.Y.; Gao, X.F.; Tam, C.M. Microstructural analysis of recycled aggregate concrete produced from two-stage mixing approach. Cem. Concr. Res. 2005, 35, 1195-1203. [CrossRef]

26. Xiao, J.; Li, W.; Sun, Z.; Lange, D.A.; Shah, S.P. Properties of interfacial transition zones in recycled aggregate concrete tested by nanoindentation. Cem. Concr. Compos. 2013, 32, 276-292. [CrossRef]

27. Sáez del Bosque, I.F.; Zhu, W.; Howind, T.; Matías, A.; Sánchez de Rojas, M.I.; Medina, C. Properties of interfacial transition zones (ITZs) in concrete containing recycled mixed aggregate. Cem. Concr. Compos. 2017, 81, 25-34. [CrossRef]

28. Djerbi, A. Effect of recycled coarse aggregate on the new interfacial transition zone concrete. Constr. Build. Mater. 2018, 190, 1023-1033. [CrossRef]

29. Hojati, M.; Rajabipour, F.; Radlińska, A. Drying shrinkage of alkali-activated cements effect of humidity and curing temperature. Mater. Struct. 2019, 52, 118-132. [CrossRef]

30. Humad, A.M.; Provis, J.L.; Ćwirzeń, A. Effects of curing conditions on shrinkagealkali-activated high-mgo swedish slag concrete. Front. Mater. 2019, 6, 287-306. [CrossRef]

31. Fonseca, N.; De Brito, J.; Evangelista, L. The influence of curing conditions on the mechanical performance of concrete made with recycled concrete waste. Cem. Concr. Compos. 2011, 33, 637-643. [CrossRef]

32. Gonzalez-Corominas, A.; Etxeberria, M.; Poon, C.S. Influence of steam curing on the pore structures and mechanical properties of fly-ash high performance concrete prepared with recycled aggregates. Cem. Concr. Compos. 2016, 71,77-84. [CrossRef]

33. Hanif, A.; Kim, Y.; Usman, M.; Park, C. Optimization of steam-curing regime for recycled aggregate concrete incorporating high early strength cement-A parametric study. Materials 2018, 11, 2487. [CrossRef]

34. Damineli, B.L.; Kemeid, F.M.; Aguiar, P.S.; John, V.M. Measuring the eco-efficiency of cement use. Cem. Concr. Compos. 2010, 32, 555-562. [CrossRef]

35. Kjellsen, K.O.; Guimaraes, M.; Nilsson, A. The $\mathrm{CO}_{2}$ Balance of Concrete in a Life Cycle Perspective; Danish Technological Institute: Taastrup, Denmark, 2005; pp. 23-30.

36. Kikuchi, T.; Kuroda, Y. Carbon dioxide uptake in demolished and crushed concrete. J. Adv. Concr. Technol. 2011, 9, 115-124. [CrossRef]

37. Ortega, J.M.; Treminó, R.M.; Sánchez, I.; Climent, M.A. Effect of environment on the microstructure and properties of sustainable mortars with fly ash and slag after a 5-year exposure period. Sustainability 2018, 10, 663. [CrossRef]

38. EN-1008:2002. Mixing Water for Concrete. Specification for Sampling, Testing and Assessing the Suitability of Water, Including Water Recovered from Processes in the Concrete Industry, as Mixing Water for Concrete. Available online: https://shop.bsigroup.com/ProductDetail/?pid=000000000019990036 (accessed on 20 May 2020).

39. EN-933-2:1999. Test for Geometrical Properties of Aggregate-Part 2: Determination of Particle Size. Available online: https://infostore.saiglobal.com/en-au/Standards/EN-933-2-1995-330015_SAIG_CEN_CEN_759342/ (accessed on 20 May 2020).

40. EN 12350-2:2009. Testing Fresh Concrete-Part 2. Slump flow. Available online: https://infostore.saiglobal. com/preview/98695517465.pdf?sku=870304_saig_nsai_nsai_2069434 (accessed on 20 May 2020).

41. EN 12350-7:2009. Testing Fresh Concrete-Part 7. Air Content. Pressure Methods. Available online: https://infostore.saiglobal.com/preview/98695940447.pdf?sku=870311_SAIG_NSAI_NSAI_2069453 (accessed on 20 May 2020).

42. EN 12350-3:2009. Testing Hardened Concrete-Part 3. Compressive strength of Test Specimens. Available online: https://infostore.saiglobal.com/preview/is/en/2009/i.s.en12390-3-2009\%2Bac-2011.pdf?sku=1117182 (accessed on 20 May 2020). 
43. Olorunsogo, F.T.; Padayachee, N. Performance of recycled aggregate concrete monitored by durability indexes. Cem. Conc. Res. 2002, 6, 179-185. [CrossRef]

44. EN 13057:2002. Products and Systems for the Protection and Repair of Concrete Structures. Test Methods. Determination of Resistance of Capillary Absorption. Available online: https://shop.bsigroup.com/ ProductDetail?pid=000000000030058207 (accessed on 20 May 2020).

(c)

(C) 2020 by the authors. Licensee MDPI, Basel, Switzerland. This article is an open access article distributed under the terms and conditions of the Creative Commons Attribution (CC BY) license (http://creativecommons.org/licenses/by/4.0/). 